\title{
Andżelika Kuźnar*, Pawet Folfas* \\ HOW DOES THE PROTECTION \\ OF INTELLECTUAL PROPERTY RIGHTS \\ AFFECT HI-TECH EXPORTS \\ FROM THE MOST ADVANCED ECONOMIES?
}

The aim of the paper is to find the relationship between the threat of the imitation of intellectual property (IP) and the exports of high-tech commodities from the five advanced economies (G-5: Germany, France, Japan, the United Kingdom and the United States) during 1970-2010. Theoretical models do not explain clearly the impact of the stronger protection of intellectual property rights (IPR) on trade. Thus, more empirical research in this area is needed.

The results show that the threat of imitation is an important factor influencing exports from the most advanced economies to all countries of the world. In the case of high and upper middle-income importers, the stronger threat of imitation (resulting from low IP protection and strong imitation abilities) results in increased exports from the five advanced economies, especially in the case of high-tech goods. Regarding low and lower middle-income importers, when the threat of imitation rises, the exports, especially of non-high-tech goods from the G-5 economies, decreases.

Keywords: intellectual property rights, development, international trade, threat of imitation

JEL Classifications: F10, F13, K33, O34

DOI: $10.15611 /$ aoe.2018.2.12

\section{INTRODUCTION}

The markets for high-technology products have been growing rapidly over the last three decades. At the same time, due to increasing global interdependence, a major issue has become the legal protection of intellectual property rights (IPR). Such protection is particularly important in cases of knowledge-intensive commodity flows, as they are often patentsensitive and threatened by the risk of imitation - these goods require more resources before they can be "discovered" (Co, 2004). Therefore, firms' decisions on their export destinations may be affected by the level of IP protection abroad. However, the theoretical models do not give a clear

\footnotetext{
* Institute of International Economics, Warsaw School of Economics.
} 
prediction about the impact of differences in IP laws on trade flows. Maskus and Penubarti (1995) formulate a hypothesis that the market expansion effect is likely to dominate in larger countries with stronger imitation abilities, while the market power effect would be stronger in smaller countries with limited imitation abilities. This has been examined empirically in several studies. Yet the results are ambiguous, with variations resulting from different country and commodity samples and groupings, different time periods, and the diversity of variables included in models.

The aim of this paper is to find the relationship between the threat of imitation of intellectual property and high-tech exports. We use a gravity model of bilateral trade flows and estimate the effects of the changing threat of imitation (IP protection combined with the abilities to imitate) on exports from five of the most advanced economies (G-5) to the rest of the world over the period 1970-2010. The exporting countries are Germany, France, Japan, the United Kingdom and the United States. Even though their individual and cumulative share in the world's exports of high-tech goods has been decreasing since the $1970 \mathrm{~s}^{1}$, they are still responsible for one third of these exports (see Figure 1). These countries are important innovators and producers of new knowledge, so their exports are likely to involve new technologies and therefore IPR protection should be more important for them. We deliberately did not include China in our research, even though it is an important exporter of high-tech goods. There are two main reasons for this exclusion. Firstly, as indicated by the analysis of trade in value added (Folfas, 2016), a significant share of exports of goods "made in China" has foreign origins. China is closely integrated with the global value chains (GVC) and participates mainly in the last stages of production and exports of final goods (Kuźnar, 2017). Secondly, contrary to the G-5 countries, China is widely known for its low respect for IPR and low human capital. The indicated fundamental differences determine that China cannot be included in the study, which we close with a general conclusion.

High-technology goods have been analyzed for two reasons: 1) they are among the most dynamic components of international trade over the last decades, and 2) they are expected to be the most affected by different IPR regimes (due to their relatively large $R \& D$ intensity). As it is widely recognized in the literature that patent rights regimes can distort trade in combination with the imitation ability of countries, we take these determinants into account in our model.

\footnotetext{
${ }^{1}$ The share of G-5 countries in total exports decreased similarly over the same period.
} 


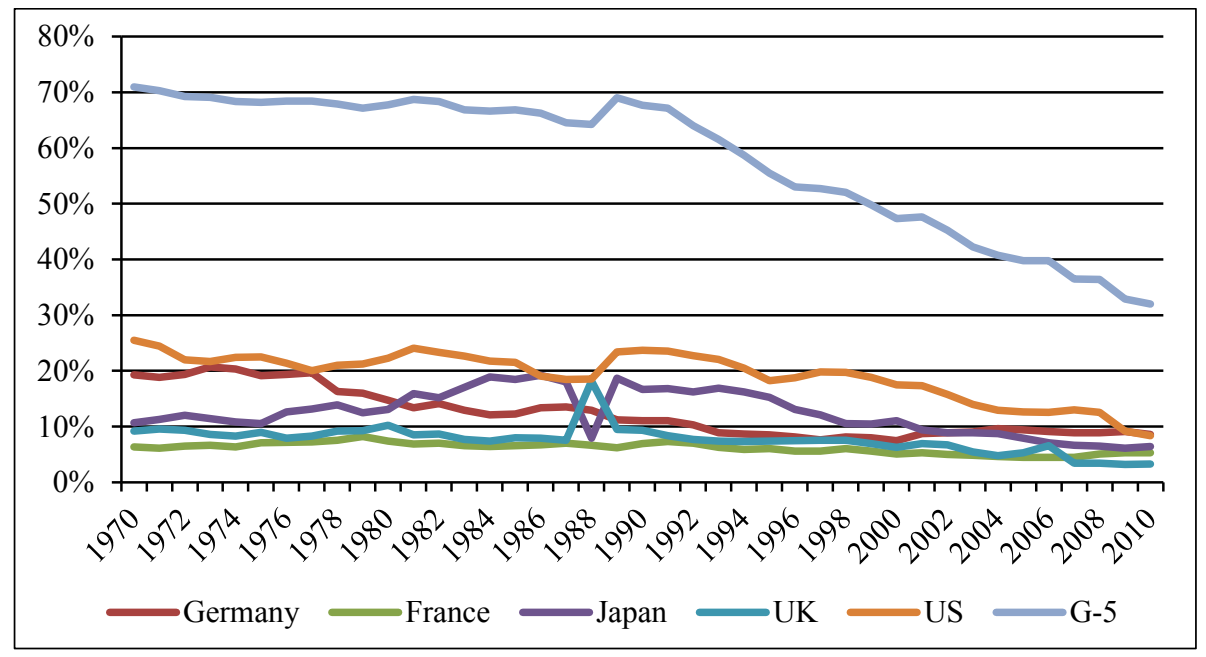

Note: 1970-1988: hi-tech classification based on SITC Rev. 1 nomenclature; 1989-2010: hi-tech classification based on SITC Rev. 3 nomenclature

Figure 1. The share of G-5 economies in world exports of hi-tech commodities in 1970-2010

Source: authors' own based on WITS-COMTRADE database, http://wits.worldbank.org (access: 22.06.2014)

This study improves on previous studies in several respects. First, we used panel data over a long period of time. Most of the literature so far used cross-section data (e.g. Maskus and Penubarti, 1995; Fink and Primo Braga, 1999; Smith, 1999; Rafiquzzaman, 2002), with some exceptions (notably Falvey, Foster and Greenaway, 2009; Ivus, 2010). Such an approach allows us to capture the relationship between IPR and trade over a period of 40 years during which the IPR laws and imitative abilities were changing dramatically in many countries. This makes results less vulnerable to business cycle or short-term regularities and allows to capture the countryspecific effects (Falvey, Foster and Greenaway, 2009). Second, we concentrated on high-technology goods, which - due to the relatively large expenditures on R\&D - should be more exposed to losses if imitated. Therefore, trade in them is likely to be more affected by the differences in IPR regimes. Third, we checked for the threat of imitation using a different proxy of imitation abilities to other research. They refer to a country's capacity to copy and produce technology and goods produced elsewhere which so far has usually been proxied by the ratio of $\mathrm{R} \& \mathrm{D}$ expenditures to GDP (Smith, 1999) and by education level indicators, such as years of 
secondary schooling, SYR (Falvey, Foster and Greenaway, 2009). While the first indicator measures innovative activity, the second focuses rather on the potential ability of the population to copy the innovation outcomes. This captures the quantity of human capital but does not say anything about its quality. That is why we use the index of human capital (HCI) per person, provided by the Penn World Table (PWT, 8.0), which is based on years of schooling and returns to education. We are aware that this is not the perfect indication of human capital development, for which the percentage of population with a certain level of education completed is also vital, but such data over a long period of time for a large group of countries are not available.

\section{INTELLECTUAL PROPERTY RIGHTS AND TRADE}

\subsection{How trade-related are IPR? The market-expansion and market-power effects}

The empirical studies of IPR and trade relationships started only in the mid-1990s. Obviously it was influenced by the then on-going Uruguay Round when IPR were also being deliberated. The growing speed of globalisation of trade and investment in the 1980s revealed the conflict between the national regulations of $\mathrm{IP}^{2}$ and the spreading use of IP all over the world. The lack of empirical studies examining the impact of variations in IPRs made the discussion of the proponents and the opponents of strengthening global IPRs lacking in any systematic evidence. The first systematic study of this issue was provided by Maskus and Penubarti (1995). Other economists developed numerical indices to characterize the strengths of patent rights (e.g. Rapp and Rozek, 1990; Ginarte and Park, 1997), which were in turn used to examine the impact of patent rights on trade, FDI or license activity.

Intellectual property rights have been labelled as trade-related and included in WTO's TRIPS agreement on the grounds of an assumption that weak and variable standards distort trade. Theoretically, IPR affect international trade flows in two opposing ways. If the IPR regime is weak,

\footnotetext{
${ }^{2}$ The international IP system at that time consisted of highly variable laws and enforcement across countries. International treaties, managed mainly by WIPO, set minimum standards for member countries, but some of them were weak and vague, and provided no effective enforcement and dispute procedures. They also lagged behind the technological advances of the 1990 s.
} 
the local firms have strong incentives to copy or imitate foreign inventions, thus replacing some imports by home production. The legal owners of IPR may refrain from exporting to a market with weak IPR because potential imitators can diminish the profitability of the firm's activity in that market. Greater IPR protection would reduce local markets' imitation and counterfeiting capabilities. Local demand is then more likely to be met by increasing imports from foreign IPR holders. Therefore, improvements in countries' IPR regimes are likely to be associated with increased exports to those countries (Maskus and Penubarti, 1995; Smith, 2001). It is possible however that the high level of protection of IPR could also prevent trade since foreign exporting firms are granted exclusive rights to products and technologies in the importing country. The rights-holding exporters benefit from the monopolistic power and decrease exports in return for higher prices and profits. This behavior depends on a variety of conditions. For example, less stringent IPR are required to ensure monopoly power when markets are segmented, when few close substitutes are available, and when imitation abilities are weak (Smith, 1999).

The overall effect of IPR protection on bilateral trade flows is theoretically ambiguous, because of opposing market-expansion and marketpower effects. It was Maskus and Penubarti (1995) who first argued that there is a trade-off between the two effects. They claimed that there is a trade-off between the increase in the quantity of exports due to the reduced abilities of local firms to imitate the product (market-expansion effect) and the enhanced market power for the firm created by stronger IP protection (market-power effect). In the first case, the imitation cost increases, thus decreasing the local production. Hence the exporter faces a demand curve shifted outward which induces larger sales. Moreover, exporters' cost of anti-imitation activities falls due to the improvement of IPR, so they can provide a larger quantity of exports. In the second case, the elasticity of demand is reduced and sales drop to maintain a high market price and profit. No clear prediction can be made about the net effect. What matters apart from the IPR strengths is local demand, the efficiency of imitative production, the structure of trade barriers, and the reactions of foreign firms granted the patent protection (Maskus and Penubarti, 1995). Thus, only empirical work can give a clearer picture.

Researchers in their empirical studies strive to find out what determines the prevailing effect. Maskus and Penubarti (1995) suggest that the marketexpansion effect would be more prevalent in larger countries with highly competitive local imitative firms, while the market-power effect would 
dominate in smaller countries with a limited capacity for imitation. Smith (1999) finds the market-expansion effect on US exports to lower middleincome countries (i.e. the high threat of imitation markets) and marketpower effect on exports to high, upper middle- and low-income countries (because of the weak threat of imitation in these countries either due to low imitation abilities or high IP standards). This approach enriches the work of Maskus and Penubarti (1995), as it considers not only the importing country's imitation ability but also the threat of imitation, defined as the ability to imitate without penalty from patent law. Strong IPR may offset the high imitation ability and result in a weak threat of imitation. The results reported in Rafiquzzaman (2002) indicate that stronger IPR have on average, across all sectors and countries, a positive influence on Canadian exports and that market power plays no role in reducing its bilateral exports. He also finds a market-expansion effect on Canadian exports to countries in all development groups, but the effect is stronger in high-income countries than in low-income countries. Finally, similarly to Smith, he suggests that the market-expansion effect applies to countries with the strongest threat of imitation, while the market-power effect exists where the threat of imitation is weakest. However, the effect is insignificant. Wen-Hsien Liu and Ya-Chi Lin (2005) found the market-expansion effect regarding Taiwanese exports to countries with strong imitation abilities, but no market-power effect to countries with weak imitation abilities (which was suggested by Maskus and Penubarti, 1995). Therefore, they support Smith's results, as Taiwan's exports increase (decrease) through the market-expansion (market-power) effect when IPRs improve in an importing country with a strong (weak) threat of imitation. They also find that an improvement in IPR has a positive impact on Taiwan's exports to countries if the importing country has a stronger R\&D ability than Taiwan. The results of empirical study carried out by Falvey, Foster and Greenaway (2009) confirm that stronger IPR are more important when the imitation ability of importing country is high. In cases of countries with low imitative abilities they find evidence of market-expansion effects for most manufacturing industries and a market-power effect for some of them. Strengthening IPR beyond the industry-specific threshold does not have a significant effect on trade flows (the threat of imitation would fall in such cases and reduce the market-expansion effect). For countries with high imitation abilities they find evidence of the marketexpansion effect in cases of industries that exhibit a market-expansion effect when imitation ability is low, but there is no evidence of changes in trade flows in industries which exhibit a market-power effect when the imitation 
ability is low. These outcomes broadly support previous studies, except that they find less evidence of a market-power effect.

Awokuse and Hong Yin (2010) confirm the market-expansion effect in China - strengthening patent laws in this large country known for a high threat of imitation led to an increase in its imports from both developed and developing countries, on average with a stronger effect in knowledgeintensive sectors (which mostly file for patents). Co (2004) finds that US exports are sensitive to IPR policies in importing countries and their imitation abilities. The findings suggest that in countries with "moderate" imitation abilities (i.e. where the research intensity is above a certain critical level), exports of R\&D intensive goods rise with patent regime stringency, implying the predominance of market-expansion effect in such a case. In cases of R\&D non-intensive goods, IPR protection has a negative and significant impact on US exports, suggesting that market-power effects dominate in this trade. Tani Fukui, Hammer and Jones (2013) found that US exports increase with the IPR protection level, more so in IP-intensive industries, thus implying the market-expansion effect.

Fink and Primo Braga (1999) found that stronger patent rights increase trade flows for the total (non-fuel) trade, whereas trade in the hightechnology sectors is not affected (the impact of IPR is slightly negative but not statistically significant). Ivus (2010) argued that the strengthening of IPR under the TRIPS agreement has led to increased developed countries' exports in patent-sensitive (relative to patent-insensitive) industries. Al-Mawali (2005) examined the effects of IPR protection on bilateral intraindustry trade (IIT) flows and found that the evidence for market-expansion effect of IPR in countries with weak imitation abilities is "surprising and not theoretically justifiable". The result of other regressions is consistent with Smith's findings as it shows the positive and statistically significant relationship between the strength of foreign IPR and South African total and vertical IIT in cases of countries with moderate and strong imitation threat, thus implying the market-expansion effect.

The market-power theory was strongly supported by the research of Yew et al. (2011). They found that China's exports to a few ASEAN countries decreased when IPR in the recipient market were strengthened. This effect is however offset by increased exports generated by the expansion of market size.

A summary of results of empirical studies regarding market-expansion and market-power effect is presented in Table 1 . The varying effects justify the need of continued research in this area. 
Table 1

Results of the most important empirical studies of the market-expansion and market-power effects

\begin{tabular}{|c|c|c|}
\hline Authors & $\begin{array}{l}\text { Market-expansion effect: } \\
\text { strengthened IPR regime leads to } \\
\text { increased exports in case of: }\end{array}$ & $\begin{array}{l}\text { Market-power effect: } \\
\text { strengthened IPR regime leads to } \\
\text { decreased exports in case of: }\end{array}$ \\
\hline $\begin{array}{l}\text { Maskus and } \\
\text { Penubarti (1995) }\end{array}$ & $\begin{array}{l}\text { - larger countries with high imitative } \\
\text { abilities }\end{array}$ & $\begin{array}{l}\text { - smaller countries with limited } \\
\text { capacity for imitation }\end{array}$ \\
\hline $\begin{array}{l}\text { Fink and Primo } \\
\text { Braga (1999) }\end{array}$ & - total non-fuel trade & $\begin{array}{l}\text { - hi-tech trade unchanged } \\
\text { (decrease of flows, but not } \\
\text { statistically significant) }\end{array}$ \\
\hline Smith (1999) & $\begin{array}{l}\text { - lower middle-income countries (high } \\
\text { threat of imitation markets) }\end{array}$ & $\begin{array}{l}\text { - high-, upper middle- and low- } \\
\text { income countries (weak threat } \\
\text { of imitation markets) }\end{array}$ \\
\hline $\begin{array}{l}\text { Rafiquzzaman } \\
(2002)\end{array}$ & $\begin{array}{l}- \text { - all sectors and countries; } \\
\text { - countries in all development groups, but } \\
\text { stronger effect in high-income } \\
\text { countries; } \\
\text { - countries that pose high threat of } \\
\text { imitation }\end{array}$ & $\begin{array}{l}\text { - countries that pose the weakest } \\
\text { threat of imitation, but the } \\
\text { effect is insignificant }\end{array}$ \\
\hline Co (2004) & \begin{tabular}{|c|c|c|}
- countries above a certain level of \\
imitative abilities
\end{tabular} & - non-R\&D intensive good \\
\hline $\begin{array}{l}\text { Liu and Lin } \\
(2005)\end{array}$ & $\begin{array}{l}\text { - countries with strong imitation abilities; } \\
\text { - countries with strong threat of imitation; } \\
\text { - countries with stronger R\&D ability } \\
\text { than Taiwan }\end{array}$ & $\begin{array}{l}\text { - countries with weak threat of } \\
\text { imitation }\end{array}$ \\
\hline $\begin{array}{l}\text { Al-Mawali } \\
(2005)\end{array}$ & $\begin{array}{l}\text { - countries with weak imitative abilities; } \\
\text { - countries with moderate and strong } \\
\text { imitation threat }- \text { total and vertical IIT }\end{array}$ & \\
\hline $\begin{array}{l}\text { Falvey, Foster } \\
\text { and Greenaway } \\
(2009)\end{array}$ & $\begin{array}{l}\text { - countries with low imitation abilities for } \\
\text { most manufacturing industries } \\
\text { - countries with high imitation abilities in } \\
\text { case of industries that exhibit market- } \\
\text { expansion effect when imitative ability } \\
\text { is low }\end{array}$ & $\begin{array}{l}\text { - countries with low imitative } \\
\text { abilities for some } \\
\text { manufacturing industries }\end{array}$ \\
\hline $\begin{array}{l}\text { Awokuse and } \\
\text { Hong Yin (2010) }\end{array}$ & $\begin{array}{l}- \text { - imports from developed and developing } \\
\text { countries to China: large country with } \\
\text { high threat of imitation; } \\
\text { - on average stronger effect in } \\
\text { knowledge-intensive sectors } \\
\end{array}$ & \\
\hline Ivus (2010) & - patent-sensitive industries & \\
\hline $\begin{array}{l}\text { Yew, Yong, } \\
\text { Cheong, Tey } \\
(2011)\end{array}$ & & $\begin{array}{l}\text { - China exports to Malaysia, } \\
\text { Philippines, Singapore and } \\
\text { Thailand }\end{array}$ \\
\hline $\begin{array}{l}\text { Fukui, Hammer, } \\
\text { Jones (2013) }\end{array}$ & $\begin{array}{l}\text { - all industries, but stronger effect in IP- } \\
\text { intensive sectors }\end{array}$ & - \\
\hline
\end{tabular}

Source: compiled by the authors. 
Table 2

Key features of empirical studies on IPR and trade

\begin{tabular}{|c|c|c|c|c|c|c|c|}
\hline Authors & $\begin{array}{l}\text { Sample } \\
\text { period }\end{array}$ & $\begin{array}{c}\text { Number } \\
\text { of importing } \\
\text { countries }\end{array}$ & $\begin{array}{l}\text { Exporting } \\
\text { countries }\end{array}$ & Model & $\begin{array}{l}\text { Measure of IPR } \\
\text { protection }\end{array}$ & Industries & Comments \\
\hline 1 & 2 & 3 & 4 & 5 & 6 & 7 & 8 \\
\hline $\begin{array}{l}\text { Maskus and } \\
\text { Penubarti } \\
\text { (1995) }\end{array}$ & 1984 & 77 & $22 \mathrm{OECD}$ & $\begin{array}{l}\text { Gravity } \\
\text { model }\end{array}$ & Rapp-Rozek Index & $\begin{array}{l}28 \text { ISIC } 3 \text {-digit industries; } \\
\text { patent-sensitive industries; } \\
\text { patent-insensitive industries; } \\
\text { all other industries }\end{array}$ & $\begin{array}{l}\text { First systematic empirical evidence on } \\
\text { the effects of IPR on international trade. }\end{array}$ \\
\hline $\begin{array}{l}\text { Fink and } \\
\text { Primo Braga } \\
(1999)\end{array}$ & 1989 & 89 & 88 & $\begin{array}{l}\text { Gravity } \\
\text { model }\end{array}$ & Ginarte-Park Index & $\begin{array}{l}\text { Aggregates for hi-tech and } \\
\text { non-fuel products }\end{array}$ & $\begin{array}{l}\text { To address the problem of zero trade } \\
\text { flows, two equations are estimated, one } \\
\text { for the probability of zero observations } \\
\text { and the other for the magnitude of } \\
\text { positive trade flows. }\end{array}$ \\
\hline Smith (1999) & 1992 & 96 & $\begin{array}{l}\text { US (each of } \\
50 \text { states plus } \\
\text { the District } \\
\text { of Colombia) }\end{array}$ & $\begin{array}{l}\text { Gravity } \\
\text { model }\end{array}$ & $\begin{array}{l}\text { Rapp-Rozek and } \\
\text { Ginarte-Park Indices }\end{array}$ & $\begin{array}{l}\text { 19 SIC 2-digit industries; } \\
\text { aggregate of manufactures and } \\
\text { patent-intensive industries; } \\
\text { disaggregated industries }\end{array}$ & $\begin{array}{l}\text { Countries grouped by four levels of } \\
\text { development and by sensitivity to the } \\
\text { threat of imitation. Threat of imitation is } \\
\text { a function of the strength of IPRs and } \\
\text { the ability to imitate foreign technology. }\end{array}$ \\
\hline $\begin{array}{l}\text { Rafiquzzaman } \\
(2002)\end{array}$ & 1990 & 76 & $\begin{array}{l}\text { Canada (10 } \\
\text { provinces) }\end{array}$ & $\begin{array}{l}\text { Gravity } \\
\text { model }\end{array}$ & $\begin{array}{l}\text { Rapp-Rozek and } \\
\text { Ginarte-Park Indices }\end{array}$ & $\begin{array}{l}22 \text { SIC 2-digit industries; } \\
\text { aggregate of manufactures and } \\
\text { patent-intensive industries; } \\
\text { disaggregated selected industries }\end{array}$ & $\begin{array}{l}\text { Countries grouped by three levels of } \\
\text { development and by sensitivity to the } \\
\text { threat of imitation. }\end{array}$ \\
\hline Co (2004) & $\begin{array}{l}1970- \\
1992\end{array}$ & 71 & USA & $\begin{array}{l}\text { Gravity } \\
\text { model }\end{array}$ & Ginarte-Park Index & $\begin{array}{l}\text { Aggregate of } 34 \\
\text { manufacturing industries; } \\
\text { R\&D and non-R\&D intensive } \\
\text { industries; disaggregated } \\
\text { selected industries }\end{array}$ & $\begin{array}{l}\text { Changes of imitation abilities and patent } \\
\text { regimes over time are controlled. }\end{array}$ \\
\hline $\begin{array}{l}\text { Liu and Lin } \\
(2005)\end{array}$ & $\begin{array}{l}1989- \\
2000\end{array}$ & 54 & Taiwan & $\begin{array}{l}\text { Gravity } \\
\text { model }\end{array}$ & Ginarte-Park Index & $\begin{array}{l}3 \text { knowledge-intensive (hi- } \\
\text { tech) industries; non- } \\
\text { knowledge-intensive industries }\end{array}$ & $\begin{array}{l}\text { Countries grouped by imitative ability, } \\
\text { threat of imitation and relative to } \\
\text { Taiwan R\&D ability. The impact of } \\
\text { TRIPS is examined. }\end{array}$ \\
\hline $\begin{array}{l}\text { Al-Mawali } \\
(2005)\end{array}$ & $\begin{array}{l}1995 \\
2000\end{array}$ & 50 & South Africa & $\begin{array}{l}\text { Gravity } \\
\text { model }\end{array}$ & Ginarte-Park Index & $\begin{array}{l}\text { Total intra-industry trade; } \\
\text { horizontal and vertical IIT }\end{array}$ & $\begin{array}{l}\text { First empirical evidence on the effects } \\
\text { of IPRs on bilateral intra-industry trade } \\
\text { flows. Countries grouped by sensitivity } \\
\text { to the threat of imitation. }\end{array}$ \\
\hline
\end{tabular}


Table 2. cont.

\begin{tabular}{|c|c|c|c|c|c|c|c|}
\hline 1 & 2 & 3 & 4 & 5 & 6 & 7 & 8 \\
\hline $\begin{array}{l}\text { Falvey, Foster } \\
\text { and } \\
\text { Greenaway } \\
(2009)\end{array}$ & $\begin{array}{l}1970- \\
1999\end{array}$ & 69 & G5 & $\begin{array}{l}\text { Gravity } \\
\text { model }\end{array}$ & Ginarte-Park Index & $\begin{array}{l}9 \text { ISIC 2-digit industries; } \\
\text { aggregate of manufactures; } \\
\text { disaggregated industries }\end{array}$ & $\begin{array}{l}\text { Countries grouped by level of } \\
\text { development, imitative ability and } \\
\text { market size using threshold regression } \\
\text { techniques. }\end{array}$ \\
\hline $\begin{array}{l}\text { Awokuse and } \\
\text { Hong Yin } \\
(2010)\end{array}$ & $\begin{array}{l}1991- \\
2004\end{array}$ & 1 (China) & $\begin{array}{l}36 \text { OECD } \\
\text { and non-- } \\
\text { OECD }\end{array}$ & $\begin{array}{l}\text { Gravity } \\
\text { model }\end{array}$ & $\begin{array}{l}\text { Ginarte-Park Index; } \\
\text { Annual patent } \\
\text { applications by } \\
\text { foreign residents } \\
\text { (firms) }\end{array}$ & $\begin{array}{l}\text { 20 SITC 2-digit industries; } \\
\text { aggregate of manufactures; } \\
\text { disaggregated industries }\end{array}$ & $\begin{array}{l}\text { The first empirical study based on one } \\
\text { developing country. Countries grouped } \\
\text { by level of development }\end{array}$ \\
\hline Ivus (2010) & $\begin{array}{l}1962- \\
2000\end{array}$ & $\begin{array}{l}55 \\
\text { (developing) }\end{array}$ & 24 OECD & $\begin{array}{l}\text { Gravity } \\
\text { model }\end{array}$ & Ginarte-Park Index & $\begin{array}{l}\text { ISIC 3-digit aggregate of } \\
\text { patent-sensitive and patent- } \\
\text { insensitive industries; } \\
\text { disaggregated patent-sensitive } \\
\text { and patent-insensitive } \\
\text { industries }\end{array}$ & $\begin{array}{l}\text { Developing countries grouped by their } \\
\text { colonial status (colonized by France or } \\
\text { Britain; non-colonized by France or } \\
\text { Britain). Pre- and post-TRIPS period } \\
\text { distinguished to capture the differences } \\
\text { in colonies and non-colonies behaviour } \\
\text { towards IPR. }\end{array}$ \\
\hline $\begin{array}{l}\text { Yew, Yong, } \\
\text { Cheong, Tey } \\
(2011)\end{array}$ & $\begin{array}{l}1993- \\
2006\end{array}$ & 5 (ASEAN) & China & $\begin{array}{l}\text { Gravity } \\
\text { model }\end{array}$ & $\begin{array}{l}\text { Global } \\
\text { Competitiveness } \\
\text { Report IPR index }\end{array}$ & All industries (total trade) & $\begin{array}{l}\text { Countries grouped by the level of } \\
\text { technology demand, proxied by the } \\
\text { location of patents by global } \\
\text { multinational companies. Foreign direct } \\
\text { investment with its complementary or } \\
\text { substitution effects with trade is } \\
\text { included as an explanatory variable. }\end{array}$ \\
\hline $\begin{array}{l}\text { Fukui, } \\
\text { Hammer, } \\
\text { Jones (2013) }\end{array}$ & $\begin{array}{l}2002- \\
2009\end{array}$ & $\begin{array}{l}\text { US trade } \\
\text { partners }\end{array}$ & USA & $\begin{array}{l}\text { Gravity } \\
\text { model }\end{array}$ & $\begin{array}{l}\text { Economist } \\
\text { Intelligence Unit } \\
\text { index }\end{array}$ & $\begin{array}{l}\text { High, moderate, low IP- } \\
\text { sensitive sectors }\end{array}$ & $\begin{array}{l}\text { A policy experiment is carried out: the } \\
\text { effect of a one-point improvement of } \\
\text { the IPR enforcement variable for all } \\
\text { countries on exports from the United } \\
\text { States is examined. }\end{array}$ \\
\hline Current study & $\begin{array}{l}1970- \\
2010\end{array}$ & $\begin{array}{l}\text { All countries in } \\
\text { the world with } \\
\text { available data } \\
\text { (ca 100) }\end{array}$ & $\begin{array}{l}\text { G5 } \\
\text { (Germany, } \\
\text { France, } \\
\text { Japan, UK, } \\
\text { USA) }\end{array}$ & $\begin{array}{l}\text { Gravity } \\
\text { model }\end{array}$ & $\begin{array}{l}\text { Ginarte-Park Index } \\
\text { (as a component of } \\
\text { variable concerning } \\
\text { threat of imitation) }\end{array}$ & $\begin{array}{l}\text { Aggregate for hi-tech and non- } \\
\text { hi-tech goods }\end{array}$ & $\begin{array}{l}\text { Importers grouped by levels of } \\
\text { development (I - high- and upper } \\
\text { middle-income countries, II - low- and } \\
\text { lower middle-income countries). }\end{array}$ \\
\hline
\end{tabular}

Source: compiled by the authors. 
Previous empirical studies vary in terms of analyzed period, number of exporting and importing countries, applied methods, selection of industries and their aggregation, measure of IPR protection and variables included in the models. The key features of the empirical studies dealing with the relationship between IPR and trade are presented in Table 2 .

Apart from the literature on the relationship of IPR to trade, there is a substantial amount of studies examining the links between IPR and nontrade channels of technology transfer, i.e. FDI and licensing. These include, among others, papers by Ferrantino (1993), Smith (2001), Park and Lippoldt (2003), Schneider (2005), Yang and Maskus (2009), Awokuse and Gu (2015). They constitute a valuable contribution to the discussion on the effects of IPR, but FDI and licensing are beyond the scope of this paper. Therefore, we do not analyze the results of these studies in our research.

\section{DATA AND METHODS}

In our empirical studies we use gravity models to analyze exports $(X)$ of goods from five advanced economies (Germany, France, Japan, the UK and the US) to all countries in the world over the period of 1970-2010 - see equation (1).

$$
\begin{gathered}
\ln \left(X_{i j t}+1\right)=\alpha_{0}+\alpha_{1} \ln G D P_{i t}+\alpha_{2} \ln G D P_{j t}+\alpha_{3} \ln D_{i j}+ \\
\alpha_{4} \ln \text { diffgdppc }_{i j t}+\alpha_{5} \text { language }_{i j}+\alpha_{6} \text { col } 5_{i j}+\alpha_{7} r t a_{i j t}+ \\
\alpha_{8} \text { volatility }_{i j t}+\alpha_{9} \text { threat }_{j t}+c_{i j}+e_{i j t},
\end{gathered}
$$

\begin{tabular}{|c|c|c|}
\hline Abbreviation & Description & Data source \\
\hline 1 & 2 & 3 \\
\hline$X_{i j t}$ & $\begin{array}{l}\text { Exports from country } i \text { to country } j \\
\text { in year } t \text { (current prices and } \\
\text { exchanges rates, USD) }\end{array}$ & $\begin{array}{l}\text { COMTRADE, The World Bank, } \\
\text { http://wits.worldbank.org, (access: } \\
\text { 20.06.2014) }\end{array}$ \\
\hline$G D P_{i j}$ & $\begin{array}{l}\text { Gross Domestic Product of country } \\
i \text { in year } t \text { (current prices and } \\
\text { exchanges rates, USD) }\end{array}$ & $\begin{array}{l}\text { WDI, The World Bank, } \\
\text { http://data.worldbank.org/data- } \\
\text { catalog/world-development-- } \\
\text { indicators, (access: } 20.06 .2014 \text { ) }\end{array}$ \\
\hline$D_{i j}$ & $\begin{array}{l}\text { Geographic distance between } \\
\text { capitals of countries } i \text { and } j(\mathrm{~km})\end{array}$ & $\begin{array}{l}\text { CEPII, http://cepii.fr (access: } \\
\text { 20.06.2014) }\end{array}$ \\
\hline $\operatorname{diffg} d p p c_{i j t}$ & $\begin{array}{l}\text { Absolute value of difference } \\
\text { between GDP per capita of country } \\
i \text { and country } j \text { in year } t \text { (current } \\
\text { prices and exchanges rates, USD) }\end{array}$ & $\begin{array}{l}\text { WDI, The World Bank, } \\
\text { http://data.worldbank.org/data- } \\
\text { catalog/world-development-- } \\
\text { indicators, (access: } 20.06 .2014 \text { ) }\end{array}$ \\
\hline
\end{tabular}

where: 
1

language $_{i j}$

$\operatorname{col} 5_{i j}$
$\mathrm{rta}_{i j t}$

volatility $_{i j t}$

threat $_{j t}$

$c_{i j}$

$e_{i j}$
2

Dummy variable that takes value 1 CEPII,
if exporter $i$ and importer $j$ use 20.06.2014)

common official language and 0

otherwise

Dummy variable that takes value 1 CEPII,
if exporter $i$ and importer $j$ had 20.06.2014)

colonial relationships before 1945

and 0 otherwise

Dummy variable that takes value 1 WTO, http://rtais.wto.org, (access:

if both trading countries $(i$ and $j$ ) 20.06.2014)

are members of regional trading

arrangements in year $t$

Exchange rate volatility measured IFS, International Monetary Fund, as a standard deviation of first http://elibrary-data.imf.org/, (access: differences of natural logarithms of 20.06.2014)

bilateral exchange rates between

currencies of country $i$ and country

$j$ in year $t$ (based on monthly

average exchange rates in SDR)

0 - weak threat of imitation, 1 - based on Ginarte-Park index* moderate threat of imitation, 2 - (Ginarte, Park 1997, Park 2008) and strong threat of imitation for index of human capital per person country $j$ in year $t$

individual country-pair effect for -

countries $i$ and $j$

error term for countries $i$ and $j$ in -

year $t$

We include standard independent variables such as: exporters and importers' GDP as well as geographic ${ }^{3}$ and economic distance between countries (the latter measured as an absolute value of the difference in GDP per capita). Additionally, our gravity models encompass three dummy variables responsible for common official language, former (before 1945) colonial relationship and membership in regional trading arrangements. We also include the exchange rate volatility.

Finally, our models contain a variable representing the threat of imitation of a commodity by an importer. In our estimates the threat of imitation depends on two variables: the strengths of patent rights and the imitation

\footnotetext{
${ }^{3}$ We use the CEPII database which contains information about the distance (in $\mathrm{km}$ ) between the main cities in countries. In most cases these are capital cities. However, in 13 out of 225 cases, apart from the calculation for the capital cities, there is also the distance for another city considered the main economic centre of the country (e.g. New York City in the USA, Toronto in Canada, or Istanbul in Turkey). This measure of distance between countries is the most commonly used proxy of the geographical distance used in gravity models.
} 
ability of importers. The first one is derived from the Ginarte-Park index, while the second one is proxied by the index of human capital per person (based on years of schooling and returns to education) published by the Penn World Table (PWT, 8.0). The Ginarte-Park index (GPI) is available for each 5 -year period from 1960 to 2005 . To use it in our models we use the GPI in 1965 for assessing the level of IP protection in 1970, and for the remaining all 5-year periods we use the consecutive available data (e.g. for the years 1971-1975 we take a GPI of 1970, for the years 2006-2010 we take a GPI of 2005 , etc.). The index takes values from zero (no protection) to five (maximum protection) and is the sum of the scores assessing the following categories: 1) extent of coverage (types of inventions that can be patented), 2) memberships in international patent treaties, 3) provisions against losses of protection, 4) existence of adequate enforcement mechanisms, 5) duration of protection.

We construct a variable threat taking three possible values: 0 when the threat is weak, 1 for moderate threat of imitation and 2 for strong threat of imitation. The three groups are created based on the following thresholds. We assume that the threat of imitation is weak if the level of intellectual property protection is high - i.e. the Ginarte-Park index exceeds 2.5 and the index of human capital is low - i.e. smaller than $2.20^{4}$. On the contrary, the Ginarte-Park index below 2.5 and human capital index greater than 2.20 signify the strong threat of imitation. In other cases, the threat of imitation is moderate.

Gravity models are estimated in terms of natural logarithms (ln). Regarding exports to handle zero exports in the sample we use the term of $\ln +1$. Including the country-pair effect $\left(c_{i j}\right)$ in the specification suggests the application of one of the typical estimators based on panel data, namely the fixed or random effects approach. However, the fixed effects approach is not adequate for models including time invariant variables - for example distance, which is one of the fundamental variables. On the contrary, the random effects approach is available also for models with time invariant variables. Additionally, this approach needs zero correlation between the individual effects and the independent variables in the model. Unfortunately, in specification illustrated by equation (1) this assumption does not hold for our models encompassing the independent variables diffgdppc $c_{i j t}$ and $r t a_{i j}$ which characterize the pair of countries. They are potentially correlated with individual effect. Consequently, the approach based on random effects is not

\footnotetext{
${ }^{4}$ This is the value of median in the sample.
} 
suitable either. In this situation there is still one approach available - the Hausman-Taylor estimation method ${ }^{5}$. It allows using both the time-varying and time invariant variables and some of them can be endogenous in the sense of correlation with individual effect but remain exogenous with respect to the error term (Czarny et al., 2011).

We estimate two types of models. One explains the exports of hi-tech commodities and the other one the exports of the remaining (non-hi-tech) goods. To distinguish hi-tech commodities, we use the OECD product classification based on the R\&D intensity (R\&D expenditure/total sales). It was first proposed in 1994 and related to the SITC Rev. 3 classification of foreign trade. As this nomenclature's trade data are only available since 1989, for the period 1970-1988 we use the list of hi-tech products based on the SITC Rev. 1 classification prepared by Fink and Primo Braga (1999). We prefer product classification over the industry classification due to several reasons. First, in the sectoral approach all R\&D is attributed to the principal activity of the firms of the given sector while the input of other sectors can be significant, thus overestimating the R\&D intensity of the given sector and underestimating it in others. Second, there is a lack of sufficiently disaggregated data for the sectors, so some products manufactured in hi-tech sectors are medium- or low-tech, while some of the products made by medium- or low-tech sectors are in fact hi-tech. The product approach excludes all products that are not hi-tech, even if they are manufactured by hi-tech industries and includes products which are hi-tech but manufactured by medium-tech sectors. Third, in the product approach data can be more easily compared between countries, because the same products are more probably classified as hi-tech in different countries (otherwise they would be different goods), while in the sectoral approach the industry may be very technology-intensive in one country and only slightly technology-intensive in another (Hatzichronoglou, 1997, pp. 7-9).

\section{THE RESULTS AND DISCUSSION}

The results of the estimations are presented in Tables 3-5. We explain the exports of the G-5 countries in two product groups (hi-tech products and all other products). Table 3 contains the results of the estimations presenting the exports to all countries of the world.

\footnotetext{
${ }^{5}$ Post-estimation comparison of the quality of models (model with fixed effects, model with random effects, H-T model) also suggests that the Hausman-Taylor model is the most appropriate.
} 
All the standard variables in both models (GDP, geographic and economic distance) are statistically significant. Positive coefficient values concerning GDP (apart from the GDP of the exporter in the model explaining the exports of hi-tech goods) prove that trade is more intensive between bigger countries, whereas the negative coefficient value referring to both geographic and economic distance shows that trade decreases with the geographic distance.

Table 3

Gravity models explaining exports from Germany, France, Japan, UK and US to all countries of the world

\begin{tabular}{l|l|c|c}
\hline \multicolumn{1}{c|}{ Variable } & \multicolumn{1}{|c|}{ Type of variable } & $\begin{array}{c}\text { Model explaining } \\
\text { exports of hi-tech } \\
\text { commodities } \\
\text { Coefficient }\end{array}$ & $\begin{array}{c}\text { Model explaining } \\
\text { exports of other } \\
\text { commodities } \\
\text { Coefficient }\end{array}$ \\
\hline $\ln G D P_{i t}$ & exogenous, time variant & $-0.08^{* * *}$ & $0.26^{* * *}$ \\
\hline $\ln G D P_{i t}$ & exogenous, time variant & $0.92^{* * *}$ & $0.73^{* * *}$ \\
\hline $\ln D_{i j}$ & exogenous, time invariant & $-0.59^{* * *}$ & $-0.79^{* * *}$ \\
\hline $\ln$ diffgdppc & endogenous, time variant & $-0.09^{* * *}$ & $-0.04^{* * *}$ \\
\hline language $_{i j}$ & exogenous, time invariant & $0.93^{* * *}$ & $0.51^{* *}$ \\
\hline col45 $_{i j}$ & exogenous, time invariant & 0.26 & $0.46^{*}$ \\
\hline rta $_{i j t}$ & endogenous, time variant & $0.17^{* * *}$ & $0.10^{* * *}$ \\
\hline volatility $_{i j t}$ & exogenous, time variant & 0.03 & $0.12^{* *}$ \\
\hline threat $_{i t}$ & exogenous, time variant & $-0.06^{* * *}$ & $-0.08^{* * *}$ \\
\hline$c_{i j}$ & - & $4.55^{* * *}$ & $1.88^{* * *}$ \\
\hline & 14917 & 14917 \\
\hline
\end{tabular}

Note: $* * * \mathrm{p}<0.01, * * \mathrm{p}<0.05, * \mathrm{p}<0.1$

Source: authors' estimations conducted in STATA.

Quite unexpected and interesting is the negative value of the coefficient concerning the GDP of the exporter in the model explaining exports of hitech goods. It shows, contrary to the theory, that exports from richer countries (higher GDP) are relatively less intensive. The probable solution of this puzzle is the huge domestic market of the United States, especially in the context of hi-tech products.

Common language matters for exports of both hi-tech and other commodities, but former colonial links matter only in the case of exports of other commodities. Regional trading arrangements are accompanied by more intensive exports, especially in the case of hi-tech products. Moreover, the variable concerning exchange rate volatility is not statistically significant or is significant, but the value of coefficient is positive. Consequently, the 
models do not confirm regularity that fluctuations in exchange rates diminish the international trade.

Finally, the models show that a stronger (weaker) threat of imitation is accompanied by less (more) intensive exports. This is true not only for hitech commodities, but also, and even more so, for other commodities. The strong (weak) threat of imitation can have different roots in developed and developing countries. Consequently, the correlation between the level of threat of imitation and intensity of trade needs to be examined in the groups of countries at different levels of development.

Therefore, we re-estimate models described by equation (1) but this time separately for two groups of importers. We distinguish these groups using the World Bank's country classification based on GNI (gross national income) per capita. Table 4 contains the estimation results for high- and upper middle-income per capita importers and Table 5 for low- and lower middle-income per capita importers.

Table 4

Gravity models explaining exports from Germany, France, Japan, UK and US to importers with high income and upper middle income per capita

\begin{tabular}{|c|c|c|c|}
\hline Variable & Type of variable & $\begin{array}{l}\text { Model explaining } \\
\text { exports of hi-tech } \\
\text { commodities } \\
\text { Coefficient }\end{array}$ & $\begin{array}{l}\text { Model explaining } \\
\text { exports of other } \\
\text { commodities } \\
\text { Coefficient }\end{array}$ \\
\hline $\ln G D P_{i t}$ & exogenous, time variant & $0.14 * * *$ & $0.21 * * *$ \\
\hline $\ln G D P_{i t}$ & exogenous, time variant & $0.78 * * *$ & $0.79 * * *$ \\
\hline $\ln D_{i j}$ & exogenous, time invariant & $-0.55 * * *$ & $-0.79 * * *$ \\
\hline $\ln$ diffgdppc $c_{i j t}$ & endogenous, time variant & $-0.07 * * *$ & $-0.03 * * *$ \\
\hline language $_{i j}$ & exogenous, time invariant & $0.88^{*}$ & $0.69 *$ \\
\hline col45 $_{i j}$ & exogenous, time invariant & -0.01 & 0.29 \\
\hline$r t a_{i j t}$ & endogenous, time variant & $0.16^{* * *}$ & $0.09 * * *$ \\
\hline volatility $_{i j t}$ & exogenous, time variant & -0.01 & -0.02 \\
\hline threat $_{j t}$ & exogenous, time variant & $0.10 * * *$ & $0.08 * * *$ \\
\hline$c_{i j}$ & - & 0.48 & 0.01 \\
\hline \multicolumn{2}{|c|}{ Number of observations } & 7440 & 7440 \\
\hline
\end{tabular}

Note: $* * * \mathrm{p}<0.01, * * \mathrm{p}<0.05, * \mathrm{p}<0.1$

Source: authors' estimations conducted in STATA.

The most important conclusion stemming from the estimation results refers to the variable representing the threat of imitation. Namely, the higher (lower) threat of imitation is accompanied by more (less) intensive exports only to the richer countries (Table 4), and the effect is slightly stronger in 
cases of hi-tech exports. As we may expect that in high- and upper-middle income countries a low threat of imitation is caused rather by strong IP protection than by weak abilities to imitation, some symptoms of the market power effect are visible in this case. However, the variable threat of imitation contains both the IP protection component and the human capital part $^{6}$, hence, we cannot exclude another explanation ${ }^{7}$.

In cases of low- and lower middle-income per capita countries, the stronger (weaker) threat of imitation is accompanied by less (more) intensive exports. If this was caused only by stronger IP protection, there would be some symptoms of the market-expansion effect, yet it could be caused by lower abilities of imitation in low- and lower middle-income countries. In this case this effect is stronger for exports of non-hi-tech goods (Table 5).

Table 5

Gravity models explaining exports from Germany, France, Japan, UK and US to importers with low income and lower middle income

\begin{tabular}{l|l|c|c}
\hline \multicolumn{1}{c|}{ Variable } & Type of variable & $\begin{array}{c}\text { Model explaining } \\
\text { exports of hi-tech } \\
\text { commodities } \\
\text { Coefficient }\end{array}$ & $\begin{array}{c}\text { Model explaining } \\
\text { exports of other } \\
\text { commodities } \\
\text { Coefficient }\end{array}$ \\
\hline $\ln G D P_{i t}$ & exogenous, time variant & $1.12^{* * *}$ & $0.72^{* * *}$ \\
\hline $\ln G D P_{i t}$ & exogenous, time variant & $0.88^{* * *}$ & $0.60^{* * *}$ \\
\hline $\ln D_{i j}$ & exogenous, time invariant & $-0.55^{* * *}$ & $-1.25^{* * *}$ \\
\hline $\ln$ diffgdppc $c_{i j t}$ & endogenous, time variant & $-1.39^{* * *}$ & $-0.44^{* *}$ \\
\hline language $_{i j}$ & exogenous, time invariant & 0.44 & $0.69^{*}$ \\
\hline col45 $_{i j}$ & exogenous, time invariant & $1.06^{* *}$ & $0.85^{* *}$ \\
\hline rta $_{i j t}$ & endogenous, time variant & $0.15^{*}$ & 0.06 \\
\hline volatility $_{i t}$ & exogenous, time variant & 0.09 & $0.17^{* * *}$ \\
\hline threat $_{i t}$ & exogenous, time variant & $-0.11^{* * *}$ & $-0.19^{* * *}$ \\
\hline$c_{i j}$ & - & $-10.83^{* *}$ & -0.21 \\
\hline Number of observations & 7461 & 7461 \\
\hline
\end{tabular}

Note: $* * * \mathrm{p}<0.01, * * \mathrm{p}<0.05, * \mathrm{p}<0.1$

Source: authors' estimations conducted in STATA.

Former colonial links are statistically significant only in models explaining exports to low- and lower middle-income countries. They are crucial (coefficient higher than 1) for exports of hi-tech commodities. It is

\footnotetext{
${ }^{6}$ Including two separate variables in the model does not solve the puzzle, as they are both statistically significant.

${ }^{7}$ Gravity models test only for correlation. The same correlation can have different reasons. Our explanation refers only to the IPR, which is the focus of interest in this study.
} 
also worth noting that the absolute value of the coefficient of variable $\ln$ diffgdppc $c_{i j t}$ in the model explaining the exports of hi-tech commodities to importers with low and lower middle income is very high (1.39 compared to only 0.07 in the model described in Table 4). This also confirms the strong influence of economic distance in the international trade of hi-tech products with the least developed economies.

\section{CONCLUSIONS}

The empirical evidence presented in this paper provide insights for determinants of policies that may be chosen by countries and producers of hi-tech goods. There is always a dilemma, whether the producers of knowledge-intensive goods (such as hi-tech commodities) should use them solely, building and enhancing their own power or of the countries of origin (by retaining the knowledge within the boundaries of the company/country) at the expense of the benefits from international trade, or maybe rather participate in trade, bearing the costs associated with the diffusion of knowledge to other entities (including competitors). Sometimes the role of knowledge in building the power of the country is so large, that even the fact of carrying out research is not revealed, not to mention the results. For example, in 2009 a consortium comprising Russian Sberbank and Canadian Magna sought to purchase Opel, which was suffering losses. The deal was not concluded (the Russians would get access to GM's know-how). At the beginning of 2017, Opel was purchased by the French PSA Group.

When choosing the option to trade, other dilemmas arise, as decisions must be made where to export. For example, there was a strict embargo on exports of advanced technologies from Western economies to the socialist bloc. The EU and NATO maintain the lists of dual-use and military goods which exports are controlled by countries to prevent the risks that these items may pose for international security. These are examples of political decisions that influence the trade policies of countries. Determining such a policy is especially complicated nowadays in the era of globalization and interconnectedness of economies and firms within GVC. The diffusion of knowledge cannot be anymore controlled by one country, because each product contains bits of knowledge of many countries, added at various stages of GVC.

One of the factors considered when deciding as to where to export is the threat of imitation in the importing country. The results of our study show 
that the threat of imitation is a significant factor influencing exports to both developed and developing economies. In cases of high- and upper middleincome importers, the stronger (weaker) threat of imitation is accompanied by more (less) intensive exports from the five advanced economies, especially of hi-tech goods. In cases of low- and lower middle-income importers, the higher (lower) threat of imitation is accompanied by less (more) intensive exports, especially of non-hi-tech goods, from the G-5 economies. The policy implication here is to generate incentives for strengthening IP protection in developing countries to decrease the threat of imitation and influence exports from advanced economies.

Future empirical studies can extend this current analysis by investigating the impact of FDI and licensing on exports of hi-tech goods, as well as including more accurate approximation of data related to the threat of imitation. The inadequacies of available statistics seem to be the most important limitation of empirical studies on international trade. Consequently, further studies based on more appropriate statistics (if available) seem to be essential.

\section{REFERENCES}

Awokuse, T. O., Yin, H., Does Stronger Intellectual Property Rights Protection Induce More Bilateral Trade? Evidence from China's Imports, "World Development", 38(8), pp. 1094 $-1104,2010$.

Co, C. Y., Do Patent Rights Regimes Matter?, "Review of International Economics”, 12(3), pp. 359-373, 2014.

Czarny, E., Folfas, P., Śledziewska, K., Witkowski, B., Wplyw integracji monetarnej na wymiane towarowa $w$ warunkach kryzysu gospodarczego [The Influence of Monetary Integration on Exchange of Goods in Economic Crisis]. Materials and Studies of The National Polish Bank, 300, pp. 1-101, 2011.

Falvey, R., Foster, N., Greenaway, D., Trade, Imitative Ability and Intellectual Property Rights, "Review of World Economics", 145, pp. 373-404, 2009.

Ferrantino, M. J., The Effect of Intellectual Property Rights on International Trade and Investment, "Weltwirtschaftliches Archiv", 129(2), pp. 300-331, 1993.

Fink, C., Primo Braga, C. A., How Stronger Protection of Intellectual Property Rights Affects International Trade Flows, Policy Research Working Paper Series 2051, The World Bank, 1999.

Folfas, P., Handel międzynarodowy mierzony wartościa brutto oraz wartościa dodana analiza porównawcza [International Commerce Measured by Gross Value and Added Value]. Oficyna Wydawnicza SGH, Warsaw, 2016.

Fukui, E. T., Hammer, A. B., Jones, L. Z., Are U.S. Exports Influenced by Stronger IPR Protection Measures in Recipient Markets?, "Business Horizons”, 56, pp. 179-188, 2013. 
Ginarte, J. C., Park, W. G., Determinants of Patent Rights: A Cross-national Study, "Research Policy", 26, pp. 283-301, 1997.

Hatzichronoglou, T., Revision of the High-Technology Sector and Product Classification, OECD Science, Technology and Industry Working Papers, 1997/02, OECD Publishing. http://dx.doi.org/10.1787/134337307632, 1997.

Ivus, O., Do Stronger Patent Rights Raise High-Tech Exports to the Developing World?, "Journal of International Economics", 81(1), pp. 38-47, 2010.

Kuźnar, A., Międzynarodowy handel produktami wiedzy [International Trade of Know-how Products]. Oficyna Wydawnicza SGH, Warsaw, 2017.

Liu, W-H., Lin, Y-C., Foreign Patent Rights and High-Tech Exports: Evidence from Taiwan, Applied Economics, 37(13), pp. 1543-1555, 2005.

Maskus, K. E., Penubarti, M., How Trade Related are Intellectual Property Rights?, "Journal of International Economics", 39, pp. 227-248, 1995.

Nasser, Al-Mawali, Bilateral Intra-industry Trade Flows and Intellectual Property Rights Protection: First Empirical Evidence, “Applied Economics Letters”, 12(13), pp. 823-828, 2005.

Park, W. G., Lippoldt, D., The Impact of Trade-related Intellectual Property Rights on Trade and Foreign Direct Investment in Developing Countries, OECD, TD/TC/WP(2002)42/FINAL, 2003.

PWT 8.0, Feenstra, R. C., Inklaar, R., Timmer, M. P., The Next Generation of the Penn World Table, available for download at www.ggdc.net/pwt, 2013.

Park, W. G., International Patent Protection: 1960-2005, "Research Policy” 37, pp. 761-766, 2005.

Rafiquzzaman, M., Impact of Patent Rights on International Trade: Evidence from Canada, "Canadian Journal of Economics", 35(2), pp. 307-330, 2002.

Schneider, P. H., International Trade, Economic Growth and Intellectual Property Rights: A Panel Data Study of Developed and Developing Countries, "Journal of Development Economics", 78(2), pp. 529-547, 2005.

Smith, P. J., Are Weak Patent Rights a Barrier to U.S. Exports?, "Journal of International Economics", 48, pp. 151-177, 1999.

Smith, P. J., How Do Foreign Patent Rights Affect U.S. Exports, Affiliate Sales, and Licenses?, "Journal of International Economics", 55, pp. 411-439, 2001.

Yang, L., Maskus, K. E., Intellectual Property Rights, Technology Transfer and Exports in Developing Countries, "Journal of Development Economics", 90, pp. 231-236, 2009.

Yew, S-Y., Yong, C-C., Cheong, K-C., Tey N-P., Does Protecting Intellectual Property Rights Matter for Trade? The Case of China's Exports to ASEAN-5, "African Journal of Business Management", 5(2), pp. 524-530, 2011.

Received: February 2015, revised: August 2017

Acknowledgements: The authors are grateful to comments received from two anonymous referees. 